\title{
"Black turbinate sign": a potential predictor of mucormycosis in cavernous sinus thrombophlebitis
}

\author{
"Sinal da concha preta": um potencial preditor de mucormicose nas tromboflebites do \\ seio cavernoso
}

Douglas Mendes Nunes', Antônio José da Rocha², Marcos Rosa Júnior¹, Carlos Jorge da Silva²
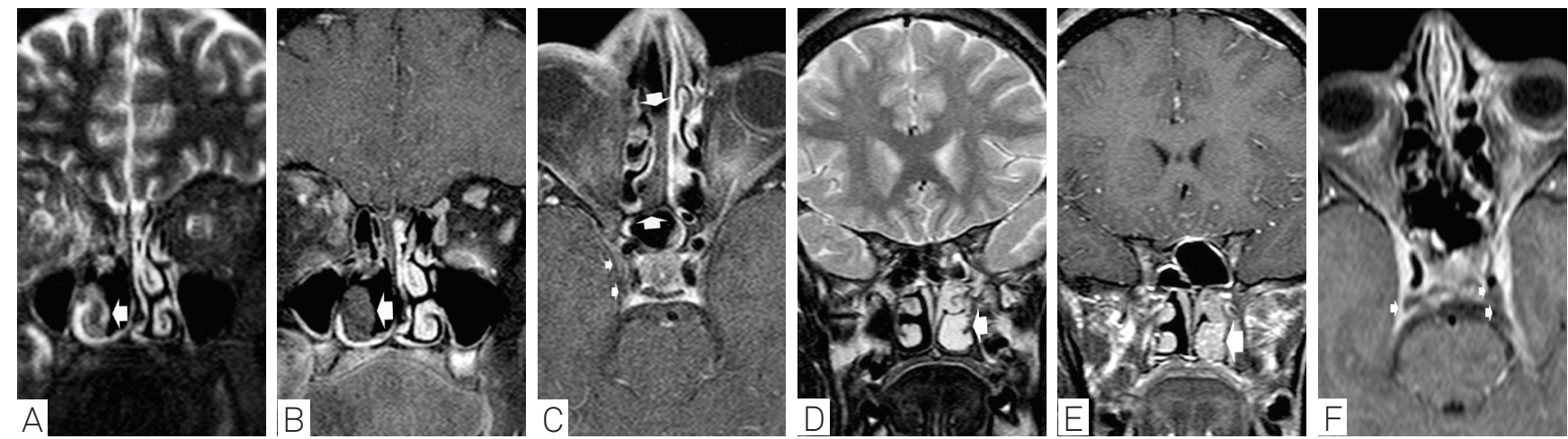

Figure. Mucormycosis exhibiting "black turbinate sign" that is characterized by low signal intensity (large arrow) of the right inferior nasal turbinate on the coronal T2 image (A) and the absence of enhancement (large arrows) after intravenous gadolinium administration on coronal (B) and axial (C) T1 images; note the typical ipsilateral CST (small arrows). The lack of these features can be observed in the comparative images of bacterial rhinosinusitis associated with bilateral CST (arrows in D-F). Both patients had additional orbital compromise.

Rhinosinusitis has the potential to result in catastrophic intracranial extension in the presence of predisposing conditions, such as diabetes, immunosuppression (fungus) or the incomplete treatment of bacterial infection. It is assumed that cavernous sinus thrombophlebitis (CST) is secondary to retrograde extension due to a valveless system of the vein that communicates paranasal cavities to the cavernous sinus ${ }^{1}$. The "black turbinate sign" results from dry gangrene in affected tissues, which presents in early stages paranasal mucormycosis. Conversely, bacterial sinusitis does not promote local necrosis and, therefore, it affects neither mucosal enhancement nor its T2 signal intensity ${ }^{2}$.

A poor prognosis of CST highlights the relevance of correct diagnosis for early treatment. The "black turbinate sign" could represent a potential discriminating feature to distinguish mucormycosis in CST etiology (Figure).

\section{References}

1. Hoxworth JM, Glastonbury CM. Orbital and intracranial complications of acute sinusitis. Neuroimaging Clin North America 2010;20:511-526.
2. Safder S, Carpenter JS, Roberts TD, Bailey N. The "black turbinate" sign: an early MR imaging finding of nasal mucormycosis. AJNR. Amer J Neuroradiol 2010;31:771-774.

\footnotetext{
${ }^{1}$ Fellow in Neuroradiology, Santa Casa de Misericórdia de São Paulo, São Paulo SP, Brazil;

${ }^{2}$ Section of Neuroradiology, Santa Casa de Misericórdia de São Paulo, São Paulo SP, Brazil.

Correspondence: Antônio José da Rocha; Rua Cincinato Braga 232; 01333-910 São Paulo SP - Brasil

Conflict of interest: There is no conflict to interest to declare.

Received 24 August 2011; Received in final form 15 September 2011; Accepted 23 September 2011
} 